Ks. Ireneusz Stolarczyk

Uniwersytet Papieski Jana Pawła II w Krakowie

Wydział Teologiczny Sekcja w Tarnowie

\title{
CZWARTY SYNOD DIECEZJI TARNOWSKIEJ O UCZESTNICTWIE ŚWIECKICH W ZBAWCZEJ MISJI KOŚCIOŁA
}

Życie społeczne opiera się na zasadach, które pozwalają kształtować je dla człowieka i ze względu na ludzkie dobro. Troska o przestrzeganie podstawowych zasad życia społecznego należy do jednej z najważniejszych funkcji władzy, dążącej do wytworzenia społecznego ładu. Odejście od realizacji zasad życia społecznego naraża społeczeństwo na błędy, które przeważnie doprowadzają do pogwałcenia praw człowieka czy też poszczególnych grup społecznych. W okresie społecznych przekształceń zauważa się narastającą dyskusję nad możliwością tworzenia nowych struktur społecznych w oparciu i z poszanowaniem wspomnianych zasad. Jest to przejaw uzasadnionej troski o skuteczne wyeliminowanie możliwych do popełnienia błędów.

W katolickiej nauce społecznej podkreśla się kilka zasad porządkujących życie społeczne: godności ludzkiej, dobra wspólnego, pomocniczości i solidarności. Nie są to wszystkie zasady etyczno-społeczne, przyjmuje się jednak, że pozostałe wykazują silny związek z wymienionymi, są innym ich przedstawieniem. Należy zauważyć, że dzięki nim można dokonać uporządkowania życia społecznego z uwagi na dobro jednostki i całych grup społecznych. Przypominają podstawową tezę, że życie społeczne znajduje swój najgłębszy sens w służbie konkretnemu człowiekowi, jest też dziełem konkretnych ludzi; wypadkową ich działań, czynów i zamierzeń. Jest to o tyle ważne, iż pozwala postrzegać życie społeczne jako efekt świadomych i wolnych działań ludzkich, nie zaś jako skutek przypadkowych zdarzeń lub pozbawiających wolności praw np. przyrody, jak przedstawiał to fizykalizm społeczny.

Skoro życie społeczne jest efektem rozumnych i wolnych działań członków życia społecznego, nie jest obojętne dla społeczeństwa to, z jakich składa się 
ono jednostek - czym są doskonalsze, tym doskonalszy będzie skutek ich działania, a więc kształt życia społecznego. Można powiedzieć jeszcze inaczej-im doskonalsi będą ludzie, tym doskonalsze będzie życie społeczne. Ojciec święty Jan Paweł II, w myśl tej zasady, przypomina że Polska nade wszystko woła dzisiaj o ludzi sumienia, a także o ludzi świętych, zdolnych budować cywilizację miłości. W ten sposób świętość jednostek ubogaca życie społeczne ${ }^{1}$. Można więc powiedzieć, że świętość ma społeczny wymiar. Niniejsze opracowanie nawiązuje do tej tezy i czyni to w kontekście refleksji IV Synodu Diecezji Tarnowskiej nad uczestnictwem świeckich w zbawczej misji Chrystusa. Istotę tej misji zawiera synodalna myśl o apostolacie katolików: „Celem apostolatu katolików świeckich jest szerzenie Ewangelii i uświęcanie siebie i drugich poprzez ożywienie i przenikanie porządku doczesnego duchem ewangelicznym w taki sposób, żeby działanie w tej dziedzinie było jawnym świadectwem o Chrystusie i przyczyniało się do zbawienia człowieka"2. W niniejszym opracowaniu teza ta zostanie ukazana na przykładzie dwóch zasad życia społecznego: zasady godności ludzkiej i dobra wspólnego.

\section{Apostolat laikatu w służbie godności człowieka}

Społeczne nauczanie Kościoła ,głosi integralną wizję człowieka, która ogarnia wszystkie wymiary jego istnienia i która wymiary materialne i instynktowne podporządkowuje wewnętrznym i duchowym"3. Pełna wizja człowieka pozwala

1 Ojciec święty Jan Paweł II w posynodalnej adhortacji apostolskiej Christifideles laici [dalej: ChL], „Acta Apostolicae Sedis” 81 (1989), s. 398, wzywa do odważnego przepajania świętością ewangeliczną wszystkich dziedzin życia społecznego: „Trzeba więc spojrzeć w twarz temu naszemu światu, spojrzeć na jego wartości i problemy, niepokoje i nadzieje, osiągnięcia i porażki; światu, którego sytuacja gospodarcza, społeczna, polityczna i kulturalna jest w porównaniu ze światem ukazanym w Konstytucji duszpasterskiej Gaudium et spes znacznie trudniejsza. Ale to on właśnie jest winnicą, to on jest polem, na którym świeccy mają wypełniać swoją misję. Jezus pragnie, by oni, tak jak wszyscy Jego uczniowie, byli solą dla ziemi i światłem świata (por. Mt 5, 13-14). A jak wygląda aktualne oblicze «ziemi» i «świata», dla których chrześcijanie winni być «solą» i «światłem»?"; ChL 3.

2 IV Synod Diecezji Tarnowskiej, Tarnów 1990, s. 211 [dalej: IV Synod...].

3 Jan Paweł II, enc. Centesimus annus [dalej: CA] 36: Dokumenty nauki społecznej Kościoła, cz. 2, Lublin 1996, s. 400. 
zachować społeczny ład, w którym „osoba ludzka jest i powinna być zasadą, podmiotem i celem wszystkich urządzeń społecznych”4.

Integralna koncepcja człowieka ukazuje całościową wizję człowieka, opartą na najgłębszej prawdzie o nim samym. Jest to prawda podkreślająca ostateczne powołanie człowieka, stworzonego na obraz Boży ${ }^{5}$, odkupionego przez Chrystusa i wezwanego do zjednoczenia z Bogiem do świętoścí. Nie ogranicza się ona zatem do wymiaru materialnego i instynktowego, ale sięga dalej do rzeczywistości wewnętrznej i duchowej, w której dokonuje się osobowe zjednoczenie z Bogiem. Takie ujęcie pozwala z jednej strony docenić świat materii, w którym człowiek tkwi i wzrasta, z drugiej - uwzględnia bogaty świat ducha, któremu świat materii jest podporządkowany. Czwarty Synod Diecezji Tarnowskiej wyraził to w krótkim stwierdzeniu nawiązującym do przenikania porządku doczesnego duchem ewangelicznym ${ }^{7}$.

Integralna koncepcja człowieka nawiązuje do klasycznej definicji Boecjusza, która głosi, że osoba ludzka jest jednostkową substancją natury rozumnej. Dociekania filozofów, próbujących ująć bogactwo człowieka w sposób wyczerpujący i thumaczący jego złożoność, pozwoliły mówić o osobie ludzkiej jako o realnej całości, złożonej z ciała i duszy. Tak więc osoba ludzka, posiadając dwie podstawowe warstwy bytu - cielesno-witalną i duchowo-intelektualną jest cielesną i duchową całością.

4 Jan Paweł II, enc. Gudium et spes [dalej: GS] 25: Dokumenty nauki społecznej Kościoła, cz. 1, Lublin 1996, s. 422.

5 Por. J. Chmiel, Człowiek obrazem Boga, „Znak” 4 (1977), s. 369.

6 Świętość osoby ludzkiej decyduje o jej wyjątkowej i niepowtarzalnej wartości o godności, którą wpisał w ludzką naturę sam Bóg. Nic nie jest w stanie tak pojętej godności odebrać człowiekowi: „Lecz świętości osoby nie da się unicestwić, choćby nie wiem jak często spotykała się z pogardą i była gwałcona. Mocno osadzona w Bogu, Stwórcy i Ojcu, świętość osoby ujawnia się zawsze i od nowa. Dlatego właśnie widzimy, jak rozprzestrzenia się dziś i coraz bardziej umacnia poczucie osobistej godności każdej ludzkiej istoty. Dobroczynny prąd przenika i ogarnia wszystkie ludy świata, które coraz lepiej uświadamiają sobie godność człowieka, a więc nie «rzeczy» lub «przedmiotu», którym można się posługiwać, ale zawsze i tylko «podmiotu», który posiada sumienie i wolność, jest wezwany do odpowiedzialnego życia w społeczeństwie i w dziejach, i podporządkowany wartościom duchowym i religijnym"; ChL 5. Tak rozumiana świętość i związana z nią godność człowieka staje się podstawową zasadą etyczno-społeczną kształtującą właściwe struktury społeczne.

7 IV Synod..., s. 211. 
Oznacza to, że osoba ludzka, związana przez potrzeby swojego ciała ze światem wegetatywnym, przekracza sferę somatyczną, odchodząc od instynktów i odruchów w kierunku działań świadomych i dobrowolnych ${ }^{8}$. Jako jedyne stworzenie jest w stanie uświadomić sobie swój cel. W duchowej naturze człowieka zawierają się rozum i wolna wola. Dzięki rozumowi - osoba ludzka może poznać prawdę, aż do Prawdy Najwyższej włącznie. Dzięki wolnej woli - może wybrać dobro, aż do Dobra Najwyższego włącznie. Osoba ludzka, jako byt samoistny, jest zdolna do określenia własnych działań. Jest to możliwe dzięki jej duchowym właściwościom - za pomocą rozumu i wolnej woli. W ten sposób dokonuje się samourzeczywistnianie - rozwój. Dokumenty synodalne precyzują cechy osobowości ludzi żyjących wiarą; cechy, które są miarą rozwoju ludzi żyjących wartościami ewangelicznymi: „Wierzących powinna charakteryzować sprawiedliwość, cierpliwość, wyrozumiałość i miłość wobec wszystkich ludzi, także podczas załatwiania spraw codziennych w urzędach, w sklepach i na ulicy"9. Można zauważyć, że w takim stwierdzeniu wyraża się prawda o związku żywej wiary, z jej skutecznym wpływem i owocnym oddziaływaniem na kształt życia społecznego.

Poruszając temat rozwoju osoby ludzkiej, dotykamy rozległej kwestii dynamicznego charakteru natury człowieka. W ludzkiej naturze zawarte są cele, które człowiek jest w stanie rozeznać i zrealizować. Jednymi z nich są cele najbliższe, inne - to cele życiowe. Życie realizowane zgodnie z naturą przynosi człowiekowi szczęście. Jest ono związane z realizacją celów wpisanych w ludzką naturę. Jest to proces rozwoju. Proces ten znajduje swoje wypełnienie w zjednoczeniu z Bogiem. Zrealizowanie tego celu łączy się z faktem, iż oprócz natury człowiek otrzymuje również łaskę, która go uzdalnia do życia w Bogu. Synod wprowadza w tym miejscu niezwykle głębokie określenie, mówiąc o służbie katolików świeckich w szerzeniu zbawczego orędzia i nadawaniu ewangelicznego znamienia doczesnemu porządkowi życia ${ }^{10}$.

Człowiek odznacza się wyjątkową wartością. Z uwagi na tę wyjątkowość mówimy o godności ludzkiej. Odczucia wyjątkowej godności człowieka znajdują swój wyraz w następujących stwierdzeniach o człowieku: „,najdoskonalszy

8 I. Dec, Osoba jako podmiot w ujęciu kard. Karola Wojtyty, „Collectanea Theologica" 3 (1987), s. 14.

9 IV Synod..., s. 213.

${ }^{10}$ Por. IV Synod..., s. 211. 
w całej naturze”, „szczyt hierarchii wszystkich bytów ziemskich”, „korona w dziele Bożego stworzenia". Można zadać pytanie, skąd wynika ta szczególna godność człowieka. W literaturze społecznego nauczania Kościoła podkreśla się w tym kontekście dwa aspekty: przyrodzony i nadprzyrodzony. Pierwszy dotyczy, poruszanej już wyżej, kwestii ludzkiej natury. Wolność i świadomość osoby ludzkiej to dwa przymioty, które pozwalają mówić o godności człowieka w aspekcie przyrodzonym. Dzięki nim człowiek rozwija się, przeżywa swój dynamizm, samorealizację, samostanowienie i odpowiedzialność za to, co czyni. Drugi aspekt godności dotyczy uczestnictwa człowieka w życiu Boga. Z uwagi na nadprzyrodzony aspekt godności człowieka możemy mówić o tym, że człowiek został wyniesiony do godności synostwa Bożego, stał się bratem Chrystusa, został zaproszony do uczestnictwa w świętości Boga ${ }^{11}$. To właśnie człowiek jest celem Bożego objawienia, do człowieka przemawiał Chrystus, dla niego cierpiał, został skazany na śmierć i zmartwychwstał. Aspekt nadprzyrodzony ludzkiej godności wyraża się również w misji Kościoła Chrystusowego, dla którego właśnie człowiek jest ,jedyną drogą”. Czwarty Synod Diecezji Tarnowskiej przypomina, że najgłębszym przeżyciem tej właśnie prawdy jest żywa wiara, która wyraża się poprzez życie Eucharystią: „Mocą Eucharystii, będącej źródłem wszelkiego apostolatu, ludzie świeccy uobecniają działanie zbawcze Kościoła w takich okolicznościach i miejscach, w których przy ich pomocy jedynie Kościół może stać się solą ziemi”'12.

Z tematem godności ludzkiej nierozerwalnie łączy się zagadnienie równości wszystkich ludzi. Równość wynika z takiej samej godności wszystkich osób ludzkich. Z uwagi na równość godności - tak w aspekcie przyrodzonym, jak i nadprzyrodzonym - mówimy o równości wszystkich ludzi. Nie zaprzecza to jednak różnorodności osób ludzkich. Zróżnicowanie ze względu na tak zwane cechy drugorzędne, na przykład cechy charakteru, zamiłowania, uzdolnienia, talenty, rasy, nie oznacza nierówności w ludzkiej godności. Cechy drugorzędne ubogacają życie społeczne i nigdy nie mogą stać się przyczyną powstawania nierówności społecznych.

${ }^{11}$ Świętość przypomina o nadprzyrodzonej godności człowieka: „Godność świeckich katolików ukazuje się nam w pełni, gdy rozważamy pierwsze i podstawowe powołanie, które Ojciec w Jezusie Chrystusie i przez Ducha Świętego kieruje do każdego z nich, powołanie do świętości, czyli do doskonałości w miłości. Święty jest najwspanialszym świadectwem godności otrzymanej przez ucznia Chrystusa"; ChL 16.

${ }^{12}$ IV Synod..., s. 213. 
Z uwagi na godność - przysługują osobie ludzkiej niepodważalne prawa, wrodzone, a nie nabyte. Te właśnie prawa, niezbywalne prawa osoby ludzkiej, nie mogą być pod żadnym pozorem naruszane, tak przez innego człowieka, jak i przez określone instytucje społeczne. Godność człowieka wyklucza także jakiekolwiek formy przedmiotowego traktowania osoby ludzkiej. Nigdy i pod żadnym pozorem człowiek nie może być traktowany jako przedmiot, środek czy narzędzie. Nie może tego czynić inny człowiek ani jakakolwiek wspólnota ludzka, nie może to również mieć miejsca w jakiejkolwiek dziedzinie życia społecznego, jak choćby w polityce czy gospodarce.

Prezentując integralną koncepcję człowieka, należy również wspomnieć o społecznym charakterze natury ludzkiej. Katolicka nauka społeczna podkreśla konieczność życia w społeczeństwie. Charakter społeczny ludzkiej natury wyraża się w fakcie, że każdy człowiek, komunikując się z innymi ludźmi, tworzy wartości, które można zrealizować tylko w społecznej współpracy. Teza ta znajduje swoje doprecyzowanie w dokumentach IV Synodu Diecezji Tarnowskiej w refleksji dotyczącej odniesienia misji laikatu do takich grup społecznych jak rodzina, środowisko zawodowe czy wspólnota narodowa ${ }^{13}$. U podstaw takiego rozumienia życia społecznego znajduje się, poruszona już wcześniej, teza o dynamicznym charakterze ludzkiej natury. $\mathrm{O}$ ile bowiem w aspekcie istnienia człowiek jest bytem samodzielnym i doskonałym, o tyle w aspekcie działania jest dynamiczny, zdolny do rozwoju i wzrastania w godności. Oczywiście działanie to, polegające na realizacji potencji tkwiącej w ludzkiej naturze, zawsze powinno być zgodne z tą naturą. Zgodność tę wyznacza więc ludzka natura, ostatecznie - Bóg,Stwórca natury.

Potencjalność ludzkiej natury i jej zdolność do zaspokajania potrzeb pozwalają człowiekowi doskonalić się w działaniu. Proces ten dokonuje się tak w wymiarze potrzeb cielesno-witalnych, jak i duchowo-intelektualnych. Nie wszystkie potrzeby mogą być zaspokojone w życiu jednostkowym. Dlatego właśnie człowiek potrzebuje innych ludzi, potrzebuje społeczności, w której - poprzez nawiązanie kontaktu z innymi ludźmi przeżywającymi podobne potrzeby - utworzy wspólne wartości, umożliwiające mu pełny rozwój. Oczywiście należy w tym miejscu podkreślić, że nie każda społeczność jest w stanie sprostać tym oczekiwaniom. Potrzebny jest cały system, określający zestaw praw i obowiązków, dzięki którym każdy człowiek - podmiot i cel życia

${ }^{13}$ Por. IV Synod ..., s. 214, 216, 219. 
społecznego - będzie miał równe szanse realizacji swego człowieczeństwa. W społecznym nauczaniu Kościoła określa się tę sytuację stwierdzeniem, iż: „człowiek w całej prawdzie swego istnienia jest i powinien być zasadą, podmiotem i celem wszystkich urządzeń społecznych" ${ }^{14}$.

\section{Apostolat laikatu ubogaceniem dobra wspólnego}

Zaprezentowana powyżej integralna koncepcja człowieka znajduje w zasadzie dobra wspólnego swoją konkretną realizację. Aby to zauważyć, należy w tym miejscu przypomnieć cechy duchowej natury człowieka. Ludzka natura jest rozumna i wolna. Człowiek zorientowany na poznanie prawdy i wybór dobra wykazuje niezwykłą dynamikę w działaniu ${ }^{15}$. Dokonujący się w ten sposób rozwój osoby ludzkiej zmierza do ciągłego wzrostu w godności, do pełnego człowieczeństwa, które swój szczyt rozwoju osiąga w Najwyższym Dobru i w Najwyższej Prawdzie. Ukazany powyżej społeczny charakter natury ludzkiej zwrócił uwagę na fakt, iż doskonalenie się poszczególnych ludzi przebiega we wspólnocie, gdzie człowiek pełniej i łatwiej osiąga własną doskonałość. To właśnie świadczy o tym, że Bóg, przez naturę, ukierunkował człowieka na życie społeczne. Prawda o efektywności jednostek zorganizowanych w społeczną kooperację znajduje swoje ukonkretnienie w dokumentach synodalnych: „Katolicy świeccy Diecezji Tarnowskiej mają bogaty dorobek historyczny w tworzeniu i przynależności do różnych kościelnych stowarzyszeń, organizacji, arcybractw, bractw i innych, które były wyrazem potrzeb danej chwili oraz odpowiadały warunkom czasu" ${ }^{\prime \prime}$.

W społecznej kooperacji ludzie mogą osiągnąć cele, których sami nie byliby w stanie zrealizować. Uświadomiony cel i rozpoznane dobro stanowią wartość. Wartość ta jest jednocześnie dobrem wszystkich członków społeczności - a więc

\footnotetext{
${ }^{14}$ GS 25 .

${ }^{15}$ Dynamika ludzkiego działania dotyczy nie tylko dążenia do osobistej doskonałości i świętości, ale także wyraża się na zewnątrz - jest imperatywem przemian doskonalących życie społeczne. Przypomina o tym Christifideles laici: „Nowe sytuacje - zarówno w Kościele, jak i w życiu społecznym, ekonomicznym, politycznym i kulturalnym - domagają się dzisiaj ze szczególną siłą zaangażowania świeckich. Bierność, która zawsze była postawą nie do przyjęcia, dziś bardziej jeszcze staje się winą. Nikomu nie godzi się trwać w bezczynności"; ChL 3.

${ }^{16}$ IV Synod..., s. 211.
} 
dobrem wspólnym; a z drugiej strony jest dobrem poszczególnych osób, czyli dobrem osobowym. W ten sposób wartości wspólne, niezależnie od ich rodzaju - gospodarcze, polityczne, społeczne - mają jednocześnie charakter osobowy. Oznacza to, że ich celem jest każdy uczestnik życia społecznego, są zorientowane na poszczególnych członków społeczeństwa. Należy również podkreślić, że nie zachodzi jakakolwiek sprzeczność pomiędzy dobrem osoby ludzkiej a dobrem wspólnym. W katolickiej nauce społecznej mówi się o podporządkowaniu dobra osoby ludzkiej dobru wspólnemu. Jednakże dotyczy to sytuacji związanej jedynie z dobrami doczesnymi, przy jednoczesnym założeniu, że owo podporządkowanie nie zaprzecza zachowaniu osobowej godności i podstawowych praw. Wynika to z założenia, że właśnie w dobru wspólnym ludzie znajdują uzupełniającą pomoc, która nie narusza ich niezależności, aktywności czy przedsiębiorczości.

Człowiek - jako istota rozumna i wolna - jest odpowiedzialny za realizację własnych celów i życiowych zadań. Tworząc życie społeczne, pragnie zrealizować te wartości wspólne, których byłby pozbawiony, pozostając poza społeczeństwem. Warto zauważyć w tym miejscu, że życie społeczne pojmowane w ten sposób jest świadomym aktem ludzkim, ogniskuje się wokół określonych dóbr, których realizacja powoduje powstanie realnych więzi pomiędzy uczestnikami życia społecznego. W miarę angażowania się w dobro wspólne człowiek realizuje siebie, wzrasta w godności. W związku z tym, iż różne osoby na różny sposób, właściwy dla swoich zdolności i potrzeb, realizują życiowe cele, zauważa się zapotrzebowanie na rozmaite dobra, a tym samym na różne społeczeństwa, zogniskowane wokół tych dóbr. Pluralizm życia społecznego wynika więc z różnorodności i bogactwa poszczególnych ludzi. W społecznym nauczaniu Kościoła istnieje teza, iż wokół różnych dóbr ogniskują się różne grupy społeczne; ile różnych dóbr - tyle różnych społeczności.

Dobro wspólne jest pojęciem bardzo szerokim. Z jednej strony podkreśla się tak zwane instrumentalne dobro wspólne, nazywane też zewnętrznym. Składają się na nie warunki, urządzenia i środki, w których ludzie znajdują najpełniejsze możliwości rozwoju swojej osobowości. Mówiąc o instytucjonalnym dobru wspólnym, można myśleć o infrastrukturze społecznej, budynkach mieszkalnych, samorządach, dochodach, fabrykach, szkołach, zieleńcach, domach towarowych, szpitalach. Istnieje również inny wymiar dobra wspólnego zwany immanentnym. Jest to miara doskonałości urządzeń społecznych wyznaczona przez ludzką naturę. W tym sensie mówi się o urządzeniach społecznych w kontekście ich 
przydatności dla rozwoju człowieka. Poszukuje się w tym ujęciu nie tyle zewnętrznego komfortu, ile pokoju, głębi i szczęścia wewnętrznego. Immanentne dobro wspólne pozwala każdemu „być kimś”. Ostatecznie warto zauważyć, że nie ma sprzeczności między tymi ujęciami; dobro wspólne ma charakter zarówno instrumentalny, jak i immanentny. Dokumenty synodalne wyraźnie podkreślają rolę katolików w procesie ubogacania dobra wspólnego. Takim dobrem wspólnym może być parafia: „Należy tworzyć w parafiach zespoły ludzi, którzy ułatwialiby chorym uczestnictwo w nabożeństwach i uroczystościach religijnych"17. Wspomnianym dobrem wspólnym może być też rodzina: „Podstawowym polem dla pracy apostolskiej laikatu jest małżeństwo i rodzina. Szczególnie w naszych polskich warunkach rodzina jest również naturalnym środowiskiem rozwoju i przekazu wartości kulturowo-narodowych"18. W dokumentach synodalnych podkreśla się również odpowiedzialność katolików za dobro wspólne środowisk zawodowych: „Podstawowym zadaniem w życiu człowieka jest praca. Należy jednak pamiętać, że nie jest ona celem w sobie, lecz jedynie środkiem do realizacji chrześcijańskiego powołania" ${ }^{19}$. Najszerszym rodzajem dobra wspólnego, do którego odwołują się dokumenty synodalne, jest dobro narodu: „Wszyscy katolicy powinni zabiegać usilnie o prawdziwe dobro narodu i odznaczać się miłością Ojczyzny"20.

Dobro wspólne sprawia, że społeczność jest czymś więcej niż matematyczną sumą jednostek. Dobro wspólne jest fundamentem społeczności, wewnętrznych kontaktów, odniesień i relacji, z drugiej zaś strony czeka na „pomnożenie” ${ }^{21}$. Wspólnota zjednoczona wokół dobra wspólnego sprawdza się dopiero w działaniu. Działanie na rzecz dobra wspólnego integruje grupę, pozwala na identyfikację z nią, przyczynia się do wzrostu poczucia tożsamości. Dzięki dobru wspólnemu członkowie społeczności mają poczucie przynależności i odrębności. Wspólne dzieło mniejszych lub większych grup angażuje wszystkich członków tych społeczności. Przez angażowanie się poszczególnych ludzi na rzecz dobra wspólnego realizuje się postawa dawania.

${ }^{17}$ IV Synod..., s. 213.

${ }^{18}$ IV Synod..., s. 214.

${ }^{19}$ IV Synod ..., s. 216.

${ }^{20}$ IV Synod..., s. 219.

${ }^{21}$ Szczególną „szansę” pomnożenia dobra wspólnego mają chrześcijanie. Sami wezwani do świętości mogą uświęcać życie społeczne. O tym ubogaceniu dobra wspól- 
Zasada dobra wspólnego zakłada jego dynamiczny charakter. W postawie dawania tkwi chęć pomnażania istniejącego już dobra wspólnego. W efekcie zamierzonych działań członków społeczności dobro wspólne nieustannie ubogaca się, rozrasta ${ }^{22}$. W ten sposób pomnaża się również ich dobro osobowe. Zasada dobra wspólnego podkreśla możliwość i powinność oddolnego - a więc od poszczególnych członków społeczności - ubogacania dobra wspólnego. Każdy uczestnik życia społecznego, niepowtarzalna osoba ludzka, w różny sposób obdarzona talentami i zdolnościami, może i powinna udzielać się na rzecz dobra wspólnego. Zogniskowana wokół tego dobra wspólnota ludzi umożliwi, przez konkretne czyny swoich członków, szybszy i pełniejszy rozwój poszczególnych ludzi - uczestników życia społecznego. Należy w tym miejscu zauważyć, że grupa jako całość zyskuje na swej tożsamości, jedności i możliwościach realizacji obranego celu właśnie poprzez żywe uczestnictwo wszystkich swoich członków w pomnażaniu dobra wspólnego. W ten sposób ludzie poświęcają się na co dzień dla drugich, pomnażają wraz z nimi dobro wspólne, jednocześnie zaś uczestniczą wraz z innymi w jego wartościach.

Można powiedzieć, że zasada dobra wspólnego polega na realizacji postawy dawania, która jest wkładem poszczególnych ludzi w życie społeczne ${ }^{23}$. Zasada dobra wspólnego określa obowiązki „od dołu” i uprawnienia „od góry”. Powinność wkładu w dobro wspólne może mieć różny charakter. Może to być działanie jednostek na rzecz dobra wspólnego małych społeczeństw, może to

nego świętością osobistego życia wspomina adhortacja Christifideles laici: „Chrzest bowiem nie odrywa świeckich od świata, lecz powierza im powołanie, które właśnie w świecie, wewnątrz świata winno się urzeczywistniać, gdyż „tam ich Bóg powołuje, aby wykonując właściwe sobie zadania, kierowani duchem ewangelicznym przyczyniali się do uświęcenia świata na ksztalt zaczynu, od wewnątrz niejako, i w ten sposób przykładem zwłaszcza swego życia promieniując wiarą, nadzieją i miłością, ukazywali innym Chrystusa"; ChL 15.

${ }^{22}$ „Coraz więcej osób i grup ludzkich obiera drogę społecznego zaangażowania, aby się urzeczywistniło pragnienie pokoju. Spotykamy tu wielu ludzi świeckich, wspaniałomyślnie zaangażowanych w życie społeczne i polityczne, prowadzących wieloraką działalność tak w ramach instytucji, jak i wolontariatu, a także w służeniu najmniejszym"; ChL 6.

${ }^{23}$ Postawa dawania dotyczy także świętości. Oznacza to uświęcanie świata. „Powołanie ludzi świeckich do świętości oznacza wezwanie do tego, by żyli oni wedle Ducha właczeni $w$ rzeczywistość doczesna, i poprzez uczestnictwo $w$ działalności ziemskiej. Raz jeszcze napomina Apostoł: «Wszystko, cokolwiek działacie słowem lub czynem, 
być działanie małych grup na rzecz dobra wspólnego większych społeczności, może to być także działanie wielkich grup społecznych, jak choćby państwa, na rzecz dobra wspólnego społeczności ogólnoświatowej. W tej ostatniej sytuacji mówi się o dobru wspólnym ludzkości.

Warto na koniec dodać, że w nauczaniu społecznym Kościoła mocno podkreśla się potrzebę świadectwa ${ }^{24}$, które jest także - w pewnym sensie - postawą dawania na rzecz dobra wspólnego. Dawanie to czerpie z wartości zawartych w Bożym Objawieniu. Najwyższa forma tego świadectwa - męczeństwo - była tak wielka, że pamięć o męczennikach przetrwała wieki, a ich świadectwo ubogaciło i nadal ubogaca pokolenia chrześcijan. Uszczegółowienie tej tezy pozwala sformułować $\mathrm{w}$ dokumentach synodalnych następujący imperatyw: „Katolicy świeccy przykładem życia oraz słowami powinni wpływać na urzędników państwowych, przypominając im zasady prawa Bożego i kościelnego"25.

Dokumenty synodalne rozwijają myśl Soboru Watykańskiego II, przypominając, że jednym z najważniejszych aspektów jedności chrześcijańskiego życia jest zgodność wiary i życia, Ewangelii i kultury. To właśnie wspomniany Sobór wzywał chrześcijan, aby „kierowani duchem Ewangelii starali się wiernie wypełniać swoje doczesne powinności. Dalecy od prawdy są ci [czytamy w dokumencie Gaudium et spes], którzy wierząc, że nie mamy tu trwałego miasta, ale szukamy przyszłego, uważają, że mogą z tego powodu zaniedbywać swoje obowiązki doczesne, nie zdając sobie sprawy, że właśnie przez wiarę są jeszcze bardziej zobowiązani do ich wypełniania, zgodnie z powołaniem, które

wszystko czyńcie w imię Pana Jezusa, dziękując Bogu Ojcu przez Niego» (Kol 3, 17). Odnosząc te słowa do świeckich Sobór kategorycznie stwierdza: «Ani troski rodzinne, ani inne sprawy świeckie nie powinny pozostawać poza sferą ich życia duchowego». Zaś Ojcowie synodalni mówią na ten temat: «Ogromne znaczenie posiada spójność życia wiernych świeckich, jako tych, którzy winni dążyć do świętości w normalnych warunkach życia zawodowego i społecznego. Dlatego w odpowiedzi na swe powołanie winni traktować codzienne zajęcia jako okazje do tego, by zbliżać się do Boga, spełniać Jego wolę i służyć innym ludziom, prowadząc ich do komunii z Bogiem w Chrystusie»"; ChL 17.

${ }^{24}$ „Żywa Ewangelia w osobie Jezusa Chrystusa jest radosną nowina, którą Kościół codziennie przepowiada i której daje świadectwo wobec wszystkich ludzi. W tym przepowiadaniu i w tym świadectwie świeccy pełnią nie tylko właściwą i niezastąpioną rolę. Za ich pośrednictwem Kościół Chrystusowy jest obecny w różnorodnych sektorach świata, jako znak oraz źródło nadziei i miłości”; ChL 7.

${ }^{25}$ IV Synod ..., s. 218. 
każdemu zostało udzielone”. Wierni starają się „wykonywać swoje doczesne zajęcia, łącząc wysiłki ludzkie, domowe, zawodowe, naukowe albo techniczne w jedną żywotną syntezę z wartościami religijnymi; bowiem kierując się ich autorytetem, wszystko przyporządkowujemy chwale Boga" ${ }^{26}$. Warto również zauważyć, że zadanie to, zainicjowane w dokumentach Soboru i rozwinięte w dokumentach Synodu, stało się owocną inspiracją dla utworzonej po latach Akcji Katolickiej Diecezji Tarnowskiej.

${ }^{26}$ GS 43 